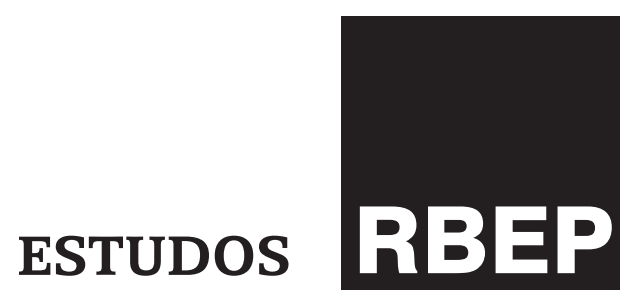

\title{
Educação e imaginário intercultural: recomposição do papel da sociedade civil
}

Manuel Gonçalves Barbosa

\section{Resumo}

Analisa, com referência às sociedades europeias, a diversificação cultural dos cenários sociais pós-coloniais e a urgente necessidade de vincular a educação, nesses contextos, a um imaginário social mais conforme a lógica inclusiva da democracia. O imaginário intercultural é visto como o novo rosto daquele imaginário e pressupõe, como condição de materialização, ampla e profunda recomposição do papel educativo da sociedade civil, como concluímos no texto.

Palavras-chave: educação; sociedade civil; diversificação cultural; cenários sociais pós-coloniais; imaginário intercultural. 


\section{Abstract \\ Education and intercultural imaginary: the recomposition of the civil society role}

This work analyzes the cultural diversification of the social post-colonial scenarios and the urgency to link education to a social imaginary in accordance to the inclusive democratic logic. The intercultural imaginary is seen as a new face of the previous one and establishes as materialization condition the wide recomposition of the civil society educational role.

Keywords: education; civil society; cultural diversification; postcolonial scenarios; intercultural imaginary.

\section{Introdução}

A questão fundamental é a forma como uma sociedade se imagina e se compreende. (Daniel Cohn-Bendit, 2010, p. 104)

O pluralismo de formas de vida e a pública manifestação de crenças religiosas são hoje moedas correntes em amplas áreas geográficas da aldeia global. A marca distintiva do tempo que atravessamos, por entre medos e incertezas, temores e perplexidades, é essa diversidade cultural e étnica que espreita em cada esquina das ruas dos nossos bairros e das nossas cidades. O uniforme, coerente e homogéneo, socialmente partilhado por todos, deu lugar ao complexo, ao plural e ao diverso. Onde víamos homogeneidade, talvez por deformação do processo de socialização, devemos ver diversidade. A diversidade é a regra. Ninguém fica imune a esta situação, quer individualmente, quer em articulação com estruturas sociais de pequena ou de grande dimensão.

Como consequência de novos fluxos de imigração, os países europeus estão a viver essa situação com algumas dores e desconforto. Manifestamente, não está a ser fácil, a esses países, viver e aceitar com elevação a sua transformação em sociedades de imigração pós-coloniais, doravante caracterizadas por toda uma panóplia de diversidades e de conflitualidades culturais.

As formações nacionais e estatais que hoje vivem, no seio da Europa, esse doloroso processo de diversificação e de multiculturalização das suas geografias e das suas paisagens são desafiadas, por razões de ética e de direito, a imaginarem-se e a compreenderem-se de outro modo, bem longe das ficções de pureza identitária e de integridade nacional monolítica. O que se afigura necessário em face dessa extraordinária 
diversificação cultural e étnica dos cenários sociais ocidentais da velha Europa é a assunção de um outro imaginário, em linha com a estridente multiculturalidade que interpela e assedia no dia a dia.

A revisão do imaginário social que nos tem guiado, em termos culturais e étnicos, é a grande aposta do momento. Já não é apropriado assobiar para o lado e fazer de conta que nada acontece à nossa volta. A presença de imigrantes de âmbitos étnicos, linguísticos e religiosos diferentes dos nossos está a dar lugar a uma acentuação dos contrastes culturais e a uma visualização pública dos diversos estilos de vida, costumes, formas de comportamento, maneiras de vestir e expressões religiosas, musicais e artísticas. A inclusão igualitária de toda esta diversidade no seio das nossas sociedades é um imperativo, pois não se pode integrar ninguém nesses espaços contra a sua cultura e a sua religião. O que precisamos, para sermos coerentes com a lógica inclusiva da democracia, é de uma paisagem construída de aspirações colectivas que incorpore, no âmago da sua semântica normativa, o respeito pela alteridade cultural dos estrangeiros e uma forma de evitar a ruptura com eles, relegando-os para espaços isolados. Ou seja, uma perspectiva de abertura e convivialidade a que se poderia chamar, grosso modo, imaginário intercultural.

O imaginário intercultural tem certamente as suas especificidades, quanto mais não seja por oposição ao imaginário assimilacionista e ao imaginário multiculturalista - a seu tempo veremos essas diferenças. Para já, importa sublinhar que esse imaginário, na medida em que traduz novas perspectivas normativas acerca da vida em comum, desafia a educação a trilhar novas sendas e novos caminhos, mais consentâneos com a civilidade em relação aos estranhos culturais, e que esse percurso, em grande parte inédito, tanto se reporta ao sistema formal de ensino como ao protagonismo, informal e não formal, da sociedade civil organizada.

A sociedade civil joga certamente um importante papel na acomodação das nossas atitudes e dos nossos comportamentos ao articulado do novo imaginário social, e nunca é de mais lembrar que a devemos convocar para essa tarefa. O nosso argumento, convergindo para esse registo e assentando na ideia que o papel educativo da sociedade civil, na óptica do imaginário intercultural, precisa de ser urgentemente reconstruído em termos pedagógicos, tem o seu ponto de partida no face a face da educação com o processo da multiculturalização, tal como ocorre, faz algum tempo, nas áreas sociais ocidentais de fluxos imigratórios pós-coloniais.

\section{A educação ante o choque da multiculturalização}

Estamos numa civilização mundial de choques, em vez de num choque de civilizações. (Arjun Appadurai, 2009, p. 25)

A diversificação cultural das sociedades europeias, sobretudo após

o período de descolonização e de incrustação, mais recente, no amplo 
e ambíguo processo da globalização, tem um efeito perturbador na educação, quer de âmbito institucional e formal, quer de natureza mais genericamente informal e não formal. Essa diversificação, a que chamamos multiculturalização, tem o poder ou a capacidade de instabilizar a educação, de mexer profundamente com os seus parâmetros directores e de desafiá-la a mudar de rumo, nomeadamente no que concerne ao atendimento à diferença cultural.

A educação, em todos os âmbitos de realização, e por maioria de razão nas sociedades democráticas do velho continente, sofre a pressão da multiculturalização e vê-se obrigada, sob o efeito dessa complexificação, a imaginar-se e a compreender-se de outro modo.

O fenómeno da multiculturalização não se processa do mesmo modo nem se exprime com as mesmas características em todo o lado. Pelo facto de ocorrer, predominantemente, em sociedades com um longo passado colonial e, desde logo, com proximidades e cumplicidades com os mais diversos povos, essa multiculturalização torna-se diferente de país para país, de região para região e de localidade para localidade. A isto acresce, no âmbito das deslocações induzidas pela globalização, o factor de atracção que certas nações hoje representam para muitos refugiados e imigrantes, alguns deles de geografias bem distantes.

A multiculturalização, enquanto processo histórico de diversificação e complexificação dos cenários sociais pós-coloniais, e não obstante as feições que adopta em linha com os factores evidenciados, é vivida em todo o lado com apreensão e como se fosse um choque entre estilos e modos de vida dissonantes. As velhas nações europeias, ainda mal refeitas do "século da barbárie" e das convulsões económicas mais recentes, descobrem subitamente que são espaços sociais multiculturais, de gritantes diferenças culturais, e que a negação dessas diferenças, no caso dos estrangeiros, pode levar a graves conflitos sociais.

As formas de vida homogéneas, imperando sem rival no seio das nações europeias, são relíquias dum passado que se desfaz sem complacências. A realidade de hoje, nessas paisagens nacionais, não é a insípida e monótona uniformidade, mas a rica e complexa diversidade.

As rígidas regulamentações estatais, por vezes ao arrepio de convenções e compromissos internacionais, bem tentam remar contra a maré da multiculturalização dentro do espaço europeu, mas a verdade é que não conseguem parar esse processo, nem mesmo à custa de polémicos repatriamentos de populações estrangeiras. A multiculturalização, pela mão da imigração, lá vai fazendo o seu caminho na velha Europa, por entre medos e receios, xenofobia e racismo, e a previsão é que assim continue, pelo menos enquanto durar essa associação estrutural entre movimentos populacionais internacionais e globalização.

Há, hoje em dia, um reconhecimento generalizado de que a mobilidade populacional transfronteiriça está inextrincavelmente ligada a outros fluxos que compõem a globalização e que as migrações são uma das principais forças de transformação social do mundo contemporâneo. (Castles, 2005, p. 44). 
Os efeitos devastadores da globalização sobre as economias dos países pobres, em particular do hemisfério sul, estão na base de movimentações migratórias desses países para os países mais ricos e desenvolvidos do hemisfério norte. A globalização económica cria condições propícias a essas movimentações, ao desencadear, nos países economicamente frágeis e pouco desenvolvidos, fenómenos de amplo desemprego, pobreza generalizada e enormes dívidas públicas. "Os movimentos migratórios de trabalhadores inserem-se numa dinâmica de desigualdade, a qual constitui certas regiões como exportadoras de mão de obra e outras em importadoras." (Sassen, 2007, p. 188).

O principal impacto da globalização, tendo em conta as migrações, está sobretudo nos factores de atracção, o mais óbvio dos quais é a perspectiva de melhor nível de vida em certos países. Se olharmos o mapa da migração, salvo raras excepções, todos os fluxos se originam em países pobres e se dirigem a países ricos. Assim, pode-se dizer que aumenta a deslocação de migrantes para certas áreas geográficas e que isso tem impactos na transformação dessas paisagens, nomeadamente em termos culturais:

Sem qualquer dúvida, a globalização está a redefinir o movimento das pessoas no mundo, tanto em termos quantitativos como qualitativos, já que aumentou o número de pessoas que emigram para os países de mais altos rendimentos, desejando manter, ao mesmo tempo, as suas identidades culturais e os laços afectivos com o seu país de origem. (Sáez Alonso, 2008, p. 229-230).

O que se passa é que os migrantes, atraídos pelas áreas geográficas mais ricas e beneficiando-se, como todo o mundo, de facilidades nas comunicações e nas deslocações, estão a salvaguardar uma ampla vinculação com a terra natal, de uma maneira bem diferente do passado:

\section{No passado, a mudança para um país estrangeiro implicava, frequentemente, cortar os laços com a pátria. Hoje, graças aos modernos canais de comunicação e aos melhores preços e rapidez das viagens, os trabalhadores imigrantes mantêm-se em contacto com o seu lugar de origem... Estes vínculos significam que é mais fácil aos imigrantes manter a sua identidade cultural numa terra estranha, ao invés do passado. (Silj, 2003, p. 434-435).}

As mudanças assinaladas são deveras significativas, pois isso quer dizer, nas circunstâncias presentes, que o imigrante vive entre dois mundos, o da origem e o do destino. Ainda que fisicamente longe do lar, continua a estar em casa, próximo dos "seus" e das suas referências. Assim, dá-se a possibilidade, quase certa, da confluência de múltiplas culturas e costumes no país de fixação migratória.

A migração e a globalização, andando de mãos dadas, ajudam a compreender a especificidade da nova imigração para o espaço europeu. O imigrante que hoje encontramos é mais cioso da sua cultura e dos seus costumes. Está a pedir, no nosso contexto, respeito e reconhecimento dessas especificidades, uma vez que não quer, ou pelo menos não dá sinais de querer, subsumir essa sua identidade nas nossas culturas maioritárias e tendencialmente hegemónicas. 
O que ele manifesta, nas arenas sociais ocidentais, é o desejo de aceitação da sua cultura como condição de integração na sociedade mais lata. Esse é um desejo com o qual devemos conviver, pois, como alerta Habermas (2010, p. 74) a propósito dos imigrantes de confissão islâmica, "não se pode integrar os imigrantes muçulmanos numa sociedade ocidental contra a sua religião, mas antes com ela". O desafio, para nós, no quadro do espaço multicultural europeu, é integrar os imigrantes sem negar as suas referências culturais, sejam novos imigrantes, sejam minorias étnicas estrangeiras que entretanto se formaram nesse quadro.

Convém assinalar, neste contexto, que o imigrante é a cara ou o rosto duma cultura diferente da nossa, tanto mais se é oriundo de geografias com outras línguas, mitos, ritos, símbolos, imaginários, expressões artísticas e expressões religiosas. Com esse imigrante não chega apenas um recurso laboral e uma variável potencial da nossa economia, chega também uma pessoa, uma pessoa "com valores e contravalores, com carências, necessidades, esperanças e expectativas" (Sáez Alonso, 2006, p. 39-40), ou seja, uma pessoa com cultura a qual configura a sua forma de pensar, sentir, actuar e interagir. Esse imigrante é mais do que mão de obra barata, disponível para tarefas sujas, arriscadas e perigosas. Não é algo, é alguém. É um outro com a sua outredade cultural - que nós precisamos para dinamizar e enriquecer a nossa cultura, os nossos horizontes pessoais e sociais.

O movimento pendular da história mostra, sem margem para dúvidas, que a migração participa activamente na transformação estrutural das sociedades e que os migrantes, verdadeiros rostos da globalização hoje em dia, optimizam a diversidade cultural, acrescentam competências, trazem ideias e são vectores de desenvolvimento.

O choque da multiculturalização, a esta luz, é uma "bênção" para as sociedades europeias, uma oportunidade que devemos agarrar, mas isso implica activar, desde já, a lógica inclusiva das democracias e mudar de imaginário social. Por um lado, a democracia tem que se reinventar para acomodar, no seu seio, a diversidade cultural que nos chega dos quatro cantos do mundo, manifestando igual respeito e consideração por todas as formas culturais compatíveis com os seus valores e os seus princípios. Por outro, é o imaginário social que precisa de se reconverter em imaginário intercultural de forma a sustentar, na presente situação europeia, uma nova modalidade de vida em comum e uma nova concepção de educação.

\section{Educação e imaginário intercultural}

\section{As imagens sobre quem somos e porque é que nos unimos têm a capacidade de dar forma aos nossos projectos. \\ (Martha Nussbaum, 2007, p. 225)}

A questão decisiva, em termos de vida colectiva, é o modo como vemos o presente e imaginamos o futuro. O presente, visto e percepcionado por uma certa franja europeia e por alguns responsáveis políticos, é de medo, 
apreensão e receio pela brusca acentuação dos contrastes culturais e pela visualização pública de credos e manifestações religiosas que, não obstante os sinais exteriores dum certo iliberalismo de convicções, reivindicam agora, e ao abrigo dos princípios democráticos, respeito, reconhecimento e ampla consideração positiva tanto nos espaços públicos como nos privados.

A exposição a esta situação no próprio âmago dos espaços nacionais europeus, e não, como outrora, no além-mar das colónias e das possessões, desencadeia uma cascata de perguntas quanto ao futuro colectivo: Será possível viver com solidariedade no meio de tanta diversidade? Como conciliar a estridente diversidade de culturas e de estilos de vida com a coesão social geral? Haverá solução para estes problemas ou teremos que regressar (se é que saímos de lá alguma vez) às velhas receitas e às velhas fórmulas assimilacionistas? Estará o futuro no regresso ao passado? Será essa a única forma de imaginar a vida em comum na suposta polis democrática das nações europeias? E se estivermos prisioneiros, como suspeita Nussbaum (2007, p. 407), de "uma imagem sobre quem somos e sobre o que é uma sociedade política" que "nos impede de imaginar outras formas de as pessoas se reunirem e decidirem viver juntas?".

A vida em comum, na verdade, pode ser imaginada de muitas maneiras, mas nem todos os imaginários se equivalem. Um imaginário social, como subentendemos aqui, não se resume a um conjunto de ideias e é bem mais amplo e profundo que as construções intelectuais que as pessoas elaboram quando fazem uma reflexão serena e distanciada sobre a realidade social onde se inscrevem como observadores e como protagonistas. O imaginário social, visto pelo prisma de Taylor (2006, p. 37), o qual adoptamos, remete antes para "o modo como as pessoas imaginam a sua existência social, o tipo de relações que mantêm umas com as outras, o tipo de coisas que ocorre entre elas, as expectativas que se cumprem habitualmente e as imagens e ideias normativas mais profundas que subjazem a estas expectativas". O imaginário social é, portanto, o modo como imaginamos a sociedade no seu conjunto, a forma de nela vivermos e nos relacionarmos, seja com os próximos (nativos como nós), seja com os estranhos, ou seja, com os culturalmente outros que vieram de fora (imigrantes, refugiados, forasteiros) ou que residem cá dentro desde longa data, como as minorias étnicas e os grupos nacionais subestatais.

As sociedades europeias, à imagem e semelhança de todas as outras, também constroem os seus imaginários, mas hoje, ante a surpreendente multiculturalização dos seus espaços, interrogam-se, com alguma perplexidade, sobre o imaginário que, adequando-se a essa realidade, não entre em contradição com a lógica inclusiva da democracia.

A lógica inclusiva da democracia, sob o ângulo da diversidade cultural e étnica, incorpora duas grandes exigências: o respeito pelas identidades diferenciais das pessoas e a recusa de qualquer separação e segregação destas em função das suas diferenças. Uma inclusão verdadeiramente democrática, politicamente construída em torno desses princípios, não só se distancia da negação do direito à diferença (assimilacionismo) como se afasta do separatismo cultural e do segregacionismo a que conduz o multiculturalismo rígido. 
A vida colectiva, nestes tempos conturbados e de grande indefinição, pode ser imaginada de muitas maneiras, mas não pode alinhar pelo assimilacionismo e pelo multiculturalismo se quiser permanecer na órbita democrática. Assimilacionismo e multiculturalismo são imaginários incompatíveis com a democracia, não apenas porque violam flagrantemente o respeito pela diversidade cultural e étnica, como podem levar, no caso do multiculturalismo, a um fraccionamento e a uma insolidariedade social, gerando divisões, crispações e polarizações identitárias entre pessoas e grupos étnicos. Se o assimilacionismo, enquanto imaginário da mesmidade, é uma violência simbólica para quem tem que renunciar à cultura própria (normalmente como moeda de troca por direitos e regalias da maioria hegemónica), já o multiculturalismo é a via mais directa para fazer da sociedade uma "colecção de comunidades étnicas" (Sen, 2007, p. 212), ou então, como diz Savater (2003, p. 171), "uma diversidade de uniformidades", eventualmente tolerantes umas com as outras, mas separadas por muros de incomunicação e levando, em espaços confinados, vidas paralelas. A esta luz, o multiculturalismo suscita preocupações quanto à coesão social dos universos sociais multiculturais e sérias dúvidas quanto à possibilidade de organizar consistentemente a vida política comum.

As reacções adversas ao multiculturalismo, principalmente no espaço europeu das sociedades de imigração pós-coloniais, fazem eco dessas dúvidas e desses receios (Triandafyllidou, 2007, p. 195-209) e estão dando lugar, no presente momento, a tentativas de regresso a abordagens de cariz assimilacionista claramente inspiradas no imaginário antropofágico da digestão/assimilação das diferenças culturais.

A vida de uma nação, ainda que multiculturalizada e pluralizada por uma vaga de culturas e religiões estrangeiras, não tem que ficar refém e muito menos oscilar, daqui para a frente, entre assimilacionismo e multiculturalismo, como únicas formas de imaginar o futuro colectivo. Se é certo que "a diversidade veio para ficar" (Sáez Alonso, 2008, p. 223) e que "os imigrantes continuarão a chegar, legal ou ilegalmente" (Giddens, 2007, p. 167), então temos que viver com esta realidade, aproveitando-a em benefício de todos, nativos e estrangeiros, no seio de uma democracia inclusiva.

Como não há modo de sair do assimilacionismo e do multiculturalismo senão pela via do interculturalismo, cremos que está neste imaginário o futuro colectivo das nações europeias. O que estas nações precisam, no amanhã que se avizinha, é de um imaginário que consagre três orientações básicas: o respeito pela dignidade cultural de todos, em particular do estranho-estrangeiro, por ser a pessoa mais vulnerável às pressões de conformidade social e cultural; a liberdade de opções culturais e étnicas acima de qualquer prerrogativa dos grupos de pertença; e, por fim, o lugar central da convivência entre indivíduos e colectividades pertencentes a horizontes culturais diferentes. Pelo lado ético, o imaginário intercultural assenta as relações no reconhecimento e na estima mútua. Pelo lado jurídico, o essencial está nas garantias de igualdade democrática enquanto "igualdade civil, igualdade de liberdades e igualdade de oportunidades" 
(Gutmann, 2008, p. 17). Pelo lado político, enfim, esse imaginário é a força inspiradora de uma sociedade aberta, onde todos tenham o seu lugar.

O imaginário intercultural, rasgando novos futuros às sociedades multiculturais pós-coloniais, e não obstante a margem de utopia que o envolve, é decisivo no traçar de novos caminhos para a educação. Esta, sob o influxo e a inspiração do imaginário intercultural, é desafiada a dar centralidade máxima às "artes de conviver permanentemente com a diferença" (Bauman, 2008, p. 133) e a perceber que tudo se joga, nas arenas sociais pouco habituadas ao convívio com estranhos culturais, no reconhecimento de uns pelos outros e na valorização mútua. O novo imaginário social induz novas modalidades de ser e estar com os outros culturalmente diferentes, e a educação, em todos os seus âmbitos, precisa de se articular com essas exigências éticas e ontológicas. Não é fácil viver juntos na diferença e com as diferenças se a educação não faz o seu trabalho de acomodação e valorização delas. O que se espera da educação, nas circunstâncias de complexa diversidade cultural e étnica em que nos encontramos, é que ajude a olhar positivamente para as diferenças e a ver nelas um meio de alargar horizontes e refinar sensibilidades.

A ideia, na verdade, não é apenas de visão, ainda que seja importante como passo prévio da acção. O que se trata, mais ambiciosamente, é de promover, por meio da educação, "o encontro, a mestiçagem, a aprendizagem e o crescimento conjunto" (Pardo, 2003, p. 73), numa base de respeito mútuo por todas as "culturas abarcadoras", isto é, segundo Gutmann (2008, p. 65), culturas que oferecem "um idioma, uma história, instituições de socialização, uma variedade de ocupações, formas de vida, tradições literárias e artísticas, formas musicais, cerimónias, festividades e costumes".

A educação, sob o signo do imaginário intercultural, não é apenas para estrangeiros e forasteiros, "dirige-se antes a todos, nativos e estrangeiros, na medida em que cada um é o estrangeiro de todos os outros" (Porcher, Abdallah-Pretceille, 1998, p. 175). O seu objectivo, mais arrojado e ambicioso que a mera pacificação das relações interétnicas, visa construir um mundo comum, feito de diálogo, de intercâmbio e de negociação, respeitando as diversidades que, pela sua natureza e constituição, não sejam atentatórias dos direitos individuais fundamentais.

O interesse pelo outro e suas culturas, no âmbito desta nova perspectiva educativa, não é mera figura de retórica nem esconde intenções eticamente reprováveis. É preciso sublinhar que a opção intercultural em educação "é a da generosidade, do reconhecimento da alteridade, do benefício mútuo através da interacção", e que o mais importante da palavra "intercultural" reside no prefixo "inter", dado subentender "a comunicação entre culturas diferentes, a articulação, a conexão, a partilha, o reconhecimento que o outro é outro e que eu sou eu, e que, ao mesmo tempo, ambos somos igualmente seres humanos, do mesmo modo" (Porcher, Abdallah-Pretceille, 1998, p. 173-174).

Uma perspectiva educacional como esta, ainda que difícil de concretizar em face de tanto racismo e xenofobia mais ou menos 
dissimulados, pode ser de grande ajuda na acomodação de atitudes e comportamentos ao ethos do novo imaginário social, no caso de ser assumida por toda a sociedade, e não apenas pela escola, uma vez que esta instituição, mais especializada na mediação do acesso ao saber e ao conhecimento, apenas pode cumprir uma parte da tarefa. Assim, outros agentes da rectificação de atitudes e comportamentos precisam de entrar em cena, como pode ser o caso da sociedade civil organizada, visto que esta instância, quando alinhada pelas coordenadas do imaginário intercultural, pode ser um importante meio de ressocialização em novas modalidades de ser e de estar com a diversidade cultural e étnica nas nossas sociedades. O que precisamos, portanto, é de uma sociedade civil sincronizada com o imaginário intercultural, e isso implica, desde já, uma recomposição do papel educativo das suas instituições e organizações estruturantes.

\section{Recomposição do papel educativo da sociedade civil}

Que se assuma no seu sentido mais pleno o novo papel da Sociedade Civil a respeito do encontro e da convivência. (José Manuel Touriñán, 2008, p. 297)

Manifestamente, "mexer" em atitudes e comportamentos não é fácil nem se realiza no imediato ou a curto prazo. Há todo um processo a percorrer que implica, durante um tempo apreciável, múltiplas instâncias e diversos agentes, desde os grupos de socialização primária até as agências de socialização secundária, passando pela família, escola, redes de sociabilidade e esse universo extremamente polifacetado de organizações e movimentos sociais que compõem a sociedade civil. A acomodação das nossas disposições mentais e das nossas práticas condutuais ao imaginário intercultural precisa do contributo de todos estes protagonistas de educação e formação e não se pode dar ao luxo de prescindir, por ignorância ou petulância, das aportações da sociedade civil, uma vez que esta instância, na pluralidade das suas formas - famílias, igrejas, sindicatos, associações empresariais, colectividades recreativas, culturais e desportivas, comunidades residenciais, associações de imigrantes, grupos étnicos e cívicos, organizações de caridade, grupos ambientalistas, movimentos sociais, clubes, grupos de ajuda, opinião pública e media não governamentais, entre tantos outros grupos e associações -, sempre incide na modelação de atitudes e comportamentos, quanto mais não seja de maneira informal e subliminar pela força do exemplo e da imitação.

A complexidade e a envergadura da missão recomendam, pois, que se assuma o protagonismo educativo da sociedade civil, comprometendo-a com o upgrade de acções e representações que impedem, pela força da inércia, a interculturalidade e a convivialidade.

O envolvimento da sociedade civil nessa tarefa precisa de estímulo e incentivos, já que dificilmente se realiza de maneira espontânea, e até pode implicar, nas situações mais gravosas, aplicação de sanções contra 
atitudes racistas e xenófobas por parte da administração da justiça num Estado de direito democrático. Seja como for, os bons ofícios da sociedade civil são sempre bem-vindos, especialmente quando são precedidos de uma recomposição do seu papel educativo em função do novo imaginário social, pois, como sabemos, também a sociedade civil tem sido vítima dos preconceitos racistas e das ideias de assimilação como único referencial da inclusão.

Uma recomposição do papel educativo da sociedade civil, na linha da interculturalidade e da convivialidade, pode abranger uma gama muito alargada de tópicos pedagógicos, embora aqui, pelos constrangimentos de espaço, apenas reteremos os principais - desde logo, a promoção de certas virtudes cívicas ou disposições ético-políticas absolutamente necessárias à aproximação e à relação entre pessoas pertencentes a horizontes culturais diferentes. Destacamos, pela sua centralidade estratégica, a virtude da civilidade e, sobretudo, a disposição para a interacção dialogante e o convívio com a alteridade cultural.

A virtude da civilidade, como evocação de urbanidade, "é a expressão quotidiana do cosmopolitismo e implica, como este, o respeito pelos outros e a aceitação da diferença" (Giddens, 2007, p. 152). A civilidade é muitas vezes identificada com as boas maneiras entre desconhecidos, mas ela é mais do que isso:

\begin{abstract}
A verdadeira civilidade não significa sorrir aos demais independentemente do mal que te fazem, como se os grupos oprimidos devessem ser amáveis com os seus opressores. Significa, antes, tratar os demais como iguais, na condição de estenderem o mesmo reconhecimento à tua pessoa. (Kymlicka, 2003, p. 350)
\end{abstract}

As normas da civilidade são normas de igualdade e precisam de entrar, para frutificar, nas mentes e nos corações das pessoas. A obrigação legal de cumprir com as normas de civilidade não garante o trato igualitário, cortês e educado entre estranhos e estrangeiros. Há que ter em conta algo mais, e esse suplemento de alma só pode vir da sociedade civil.

A disposição para a interacção dialogante e o convívio com os outros culturalmente diferentes, um pouco à semelhança da civilidade, e talvez mais do que ela, dado não estar enquadrada em dispositivos normativos, está fundamentalmente dependente dos incentivos da sociedade civil. São os estímulos dessa sociedade, desde o âmbito da família até os espaços abertos da esfera pública, passando por redes de sociabilidade no interior de grupos e associações, que levam as pessoas a dialogar e a conviver com estranhos culturais. O convívio com esses estranhos só pode acontecer na base da interacção dialógica, e esta - sob a forma de conversação honesta e civilizada, simétrica e igualitária, sem receios e medos, aberta aos mútuos questionamentos e à aceitação como condição básica "de que é possível procurar juntos a verdade e a justiça" (Todorov, 2008, p. 285) - muito depende das instituições da sociedade civil. Uma conversação assumida e valorizada por essas instituições ajuda a compartilhar o espaço social com pessoas de identidades diferentes, a aprender com elas e a 
construir uma base de entendimento mútuo, inclusive quando abundam as discrepâncias:

A conversação entre diferentes identidades - entre diferentes religiões, raças, etnias e nacionalidades - vale a pena porque permite aprender das pessoas que têm ideias diferentes, inclusive incompatíveis com as nossas. E também vale a pena porque, se aceitamos a ideia de que vivemos num mundo com diversas pessoas e nos propomos conviver com elas em respeitosa paz, necessitaremos de nos entender mutuamente, inclusivamente se não estamos de acordo. (Appiah, 2008, p. 20-21).

A conversação, segundo este autor (2007, p. 124), não é apenas um diálogo ou uma simples conversa, é essencialmente uma metáfora da inclusão na experiência e nas ideias dos outros. O mais importante da conversação não é o consenso ou a conversão desses outros às nossas perspectivas, é antes a aproximação que pode gerar entre estranhos culturais no seio das sociedades multiculturais. Como diz Appiah (2007, p. 124), "basta que contribua para que as pessoas se acostumem umas às outras".

O ajustamento pedagógico da sociedade civil a um imaginário cujas ideias centrais são a convivialidade e a interculturalidade não se reporta, exclusivamente, a virtudes cívicas ou a disposições ético-políticas, nem se confina, epistemicamente falando, a um alargamento de horizontes cognitivos sobre as culturas em presença nos contextos da interacção diária. Abarca também, como alinhamento estratégico, o desenvolvimento de certas competências, por exemplo, "o saber dialogar com as diferenças sem ferir susceptibilidades", "o saber compreender o diferente", nomeadamente quando não se está de acordo com práticas e costumes que, sendo porventura desagradáveis ou esteticamente repulsivos, não violam os direitos individuais fundamentais, ou, ainda, "o saber negociar significados" e "um modus convivendi agradável" (Bauman, 2007, p. 126).

Um dos tópicos a levar em linha de conta nesta reconfiguração ou recomposição do papel educativo da sociedade civil no sentido da construção de relações mais amigáveis entre estranhos culturais é, nos dias de hoje, uma educação dos sentimentos. Por que a educação dos sentimentos? Não serão os conhecimentos suficientes, em particular os que devem ser ministrados pelas instituições escolares? Manifestamente, é pouco provável chegar a uma sociedade simultaneamente convivial e intercultural apenas por meio de conhecimentos multiculturais, na verdadeira acepção da palavra. De facto, o que fazer perante a rigidez das posições afectivas em relação aos outros culturalmente diferentes, muitas vezes em vigor nas sociedades contemporâneas? Não será isso motivo suficiente para realizar, desde a sociedade civil, uma revisão dos sentimentos, em especial dos que rompem com a relação e a comunicação? A convivialidade assenta sobretudo em afectos e não há como esconder esta realidade. Mais vale investir na sua adequação a um mundo de estranhos culturais do que acreditar, erroneamente, que basta a compreensão intelectual das diferenças para viver juntos na sociedade multicultural.

A vida em comum nessa sociedade, por depender de uma reconversão dos afectos, é uma construção de longa duração e precisa, além de uma 
educação dos sentimentos, de uma socialização na diversidade, que, vista sob o prisma do imaginário intercultural, tem como ambição a sistemática exposição de toda a gente a toda a gente, a fim de que as pessoas se tornem menos estranhas umas das outras e reaprendam, ou simplesmente aprendam, "a arte da convivência diária com as diferenças" (Bauman, 2008, p. 36). Uma socialização na diversidade, realizada em meios heterogéneos e contando com o precioso apoio da sociedade civil, ajuda a vencer o medo dos estranhos, a dissipar os temores ao desconhecido e a adquirir, in vivo, as competências interculturais que a vida em comum exige ou solicita, como é o caso do saber escutar, traduzir, dialogar, confrontar e negociar.

O caminho da socialização na diversidade - hoje contrariado por uma certa tendência a socializar em ilhas de similitude e semelhança, em que os outros não surpreendem enquanto outros, pois pertencem ao círculo dos iguais - é um caminho sinuoso e cheio de obstáculos. A sociedade civil, na linha do que o Estado pode fazer nas escolas públicas, pode servir de amortecedor ao choque provocado por esses obstáculos e, assim, abrir, desde as suas esferas, o horizonte da convivialidade e da interculturalidade.

A abertura desse horizonte é uma janela de oportunidade para humanizar as relações sociais no seio das sociedades multiculturais, mas isso só se realizará, epistemologicamente falando, com o desenvolvimento de uma nova forma de ver os outros não só como iguais nem só como diferentes, mas simultaneamente iguais e diferentes. A esta forma de encarar os outros, sem ênfase essencialista na diferença e sem dissolução dessa mesma diferença no céu estrelado do universalismo abstracto, podemos chamar, com Beck (2005, p. 71), "olhar cosmopolita", o qual, como último tópico da recomposição pedagógica da sociedade civil, procura temperar o respeito pela diferença (o outro é diferente e posso aprender com as suas diferenças) com o respeito pelos seres humanos enquanto humanidade comum, com os mesmos desejos, os mesmos temores e as mesmas aspirações. Por meio desse olhar, "as diferenças não são nem eliminadas nem ordenadas hierarquicamente, antes aceites como tais, valorizadas positivamente" (Beck, Grande, 2006, p. 33). Os outros culturalmente diferentes, apesar da sua estranha diferença, das suas práticas e das suas crenças, são seres como nós, pertencentes à mesma categoria e à mesma natureza. Assim, não têm que ser vistos nem avaliados como uma ameaça, como algo que desintegra ou fragmenta, mas como algo que enriquece, que alarga o horizonte da compreensão e da própria liberdade. Sob os auspícios do olhar cosmopolita, a diferença é esbatida sem ser suprimida. Aceita-se a diferença, mas não se transforma em algo absoluto. Assim, abrem-se canais à comunicação com o outro, ao seu reconhecimento e à sua integração nas redes de interacção da sociedade civil, acabando com fissuras e dualismos ("nós aqui, os outros ali") manifestamente empobrecedores e comprometedores da sã convivência entre estranhos culturais. A ter em conta este ganho, é bom que a sociedade civil se comprometa com o desenvolvimento de uma nova forma de ver o outro, assente na igualdade e na diferença, no que é estranho e no que é familiar, não para 
impor uma visão do outro, o que só geraria rejeição generalizada, mas para ensinar a ver com outros olhos a alteridade cultural, aquela que verdadeiramente surpreende na sociedade multicultural.

O compromisso da sociedade civil com o imaginário intercultural passa necessariamente por esta tópica pedagógica, mas não se pense, nem por um instante, que esse compromisso é a panaceia, a curto prazo, de mudanças revolucionárias nas relações sociais em contextos multiculturais. O medo ao estranho é difícil de vencer, tanto mais se é acompanhado por desafios à nossa identidade e à nossa segurança, quer individual, quer colectiva. Ainda assim, o apoio da sociedade civil é bem-vindo para alterar essas relações, em particular nas sociedades que estão a viver o doloroso processo da sua transformação em sociedades de imigração pós-coloniais. Não nos podemos dar ao luxo, ante a amplitude e a durabilidade da tarefa, de prescindir dos "serviços" da sociedade civil, até porque é nas suas arenas que muito se joga o futuro imaginado de convivialidade e interculturalidade entre pessoas pertencentes a culturas diferentes.

\section{Referências bibliográficas}

APPADURAI, Arjun. O medo ao pequeno número: ensaio sobre a geografía da raiva. São Paulo: Iluminuras, 2009.

APPIAH, Kwame. Cosmopolitismo: la ética en un mundo de extraños. Buenos Aires: Katz, 2007. . Mi cosmopolitismo. Buenos Aires: Katz, 2008.

BAUMAN, Zygmunt. Tiempos líquidos: vivir en una época de incertidumbre. Barcelona: Tusquets Editores, 2007.

Archipiélago de excepciones. Buenos Aires: Katz, 2008.

BECK, Ulrich. La mirada cosmopolita o la guerra es la paz. Barcelona: Paidós, 2005.

BECK, Ulrich; GRANDE, Edgar. La Europa cosmopolita: sociedad y política en la segunda modernidad. Barcelona: Paidós, 2006.

CASTLES, Stephen. Globalização, transnacionalismo e novos fluxos migratórios: dos trabalhadores convidados às migrações globais. Lisboa: Fim de Século, 2005.

COHN-BENDIT, Daniel. Qué hacer? Pequeño tratado de imaginación política. Barcelona: RBA, 2010. 
GIDDENS, Anthony. Europa en la era global. Barcelona: Paidós, 2007.

GUTMANN, Amy. La identidad en democracia. Buenos Aires: Katz, 2008.

HABERMAS, Jürgen. Ay, Europa: pequeños escritos políticos. Madrid: Editorial Trotta, 2010.

KYMLICKA, Will. La política vernácula: nacionalismo, multiculturalismo y ciudadanía. Barcelona: Paidós, 2003.

NUSSBAUM, Martha. Las fronteras de la justicia: consideraciones sobre la exclusión. Barcelona: Paidós, 2007.

PARDO, Morollón. La diversidad cultural y sus conflictos, un camino hacia la interculturalidad. In: SANTOS GUERRA, M. A. (Coord.). Aprender a convivir en la escuela. Madrid: Ediciones Akal, 2003. p. 67-86.

PORCHER, Louis; ABDALLAH-PRETCEILLE, Martine. Étique de la diversité et éducation. Paris: PUF, 1998.

SÁEZ ALONSO, Rafael. Vivir interculturalmente: aprender un nuevo estilo de vida. Madrid: Editorial CCS, 2006.

SÁEZ ALONSO, R. Emigración, sociedad civil, nueva civilización. In: TOURIÑÁN, J. M. (Dir.). Educación en valores, sociedad civil y desarrollo cívico. La Coruña: Netbiblo, 2008. p. 221-239.

SASSEN, Saskia. Una sociología de la globalización. Buenos Aires: Katz, 2007.

SAVATER, F. Las etnias contra los ciudadanos. In: ECHEVERRÍA, F. (Coord.). Ética para la sociedad. Valladolid: Universidad de Valladolid, 2003. p. 163-174.

SEN, Amartya. Identidad y violencia: la ilusión del destino. Buenos Aires: Katz, 2007.

SILJ, A. Globalización y migración. In: BENEYTO, V. (Dir.). Hacia una sociedad civil global. Madrid: Taurus, 2003. p. 423-448.

TAYLOR, Charles. Imaginarios sociales modernos. Barcelona: Paidós, 2006.

TODOROV, Tzvetan. La peur des barbares: au-delà du choc des civilisations. Paris: Robert Laffont, 2008. 
TOURIÑÁN, J. M. La educación para la convivencia ciudadana: una responsabilidad compartida y derivada de formación para el desarrollo cívico. In: TOURIÑÁN, J. M. (Dir.). Educación en valores, sociedad civil y desarrollo cívico. La Coruña: Netbiblo, 2008. p. 284-310.

TRIANDAFYLLIDOU, A. Une approche européenne du défi posé par l'intégration des immigrés. In: GEREMEK, B; PICHT, R. (Dir.). Visions d'Europe. Paris: Odile Jacob, 2007. p. 195-209.

Manuel Gonçalves Barbosa, doutor em Educação pela Universidade do Minho, é professor no Departamento de Teoria da Educação e Educação Artística e Física do Instituto de Educação da Universidade do Minho, Braga-Portugal.

mbarbosa@ie.uminho.pt

Recebido em 7 de junho de 2011.

Aprovado em 29 de setembro de 2011. 